\title{
A study to identify clinical and laboratory parameters in cases of excessive vomiting in early pregnancy
}

\author{
Dyuti Dubey, Usha Agrawal*, Rekha Sapkal
}

Department of Obstetrics and Gynaecology, People's College of Medical Science and Research Centre, Bhopal, Madhya Pradesh, India

Received: 27 October 2021

Accepted: 11 November 2021

*Correspondence:

Dr. Usha Agrawal,

E-mail: ushajai2007@yahoo.co.in

Copyright: () the author(s), publisher and licensee Medip Academy. This is an open-access article distributed under the terms of the Creative Commons Attribution Non-Commercial License, which permits unrestricted non-commercial use, distribution, and reproduction in any medium, provided the original work is properly cited.

\section{ABSTRACT}

Background: Around half of all pregnant women experience vomiting, and more than $80 \%$ of women experience nausea in the first 12 weeks. Women with severe nausea and vomiting during pregnancy may have hyperemesis gravidarum (HG), an entity distinct from nausea and vomiting of pregnancy (NVP), which if left untreated may lead to significant maternal and foetal morbidity. In our study, we studied, clinical and laboratory parameters in patients presenting with excessive vomiting. The study may help in evaluating what is the major clinical problem encountered during treatment and how many days of care are needed in such cases.

Methods: The study design was a prospective observational study. Patients attending the ANC clinic and emergency indoor cases at Peoples college of medical sciences, Bhopal were considered as study population. 100 patients who satisfied inclusion and exclusion criteria were included in the study. Patient's sociodemographic variables, detailed obstetric history, clinical and laboratory parameters were recorded. Results obtained were analysed and tabulated.

Results: Persistence of vomiting in the first trimester leading to dehydration and hospitalization was documented in $12 \%$ of patients. The $5 \%$ of then had metabolic acidosis and $1 \%$ required correction of starvation ketoacidosis, but there was not significant weight loss observed in any of the case. Liver function test were normal in almost in all cases except 9\% had raised serum alkaline phosphatase levels.

Conclusions: All cases with vomiting in early pregnancy should receive attention and exclusion of all emergency clinical conditions. Patient should be screened for urine tract infection and diabetes in all cases.

Keywords: Early pregnancy, Vomiting, HG, Dehydration

\section{INTRODUCTION}

Pregnancy is a state during which the pregnant mother undergoes significant anatomical and physiological changes in order to nurture and accommodate the developing foetus. These changes begin after conception and affect every organ system in the body. For most women experiencing an uncomplicated pregnancy, these changes resolve after pregnancy with minimal residual effects. ${ }^{1}$ Around half of all pregnant women experience vomiting, and more than $80 \%$ of women experience nausea in the first 12 weeks. It is often called morning sickness as the symptoms are usually worse in the morning but can occur at any time of the day, and sometimes continue throughout the day. Women with severe nausea and vomiting during pregnancy may have $\mathrm{HG}$, an entity distinct from NVP, which if left untreated may lead to significant maternal and foetal morbidity. ${ }^{2}$ Although most women with NVP have symptoms limited to the first trimester, a small percentage of women have a prolonged course with symptoms extending until delivery. ${ }^{3}$ Nausea and vomiting typically commence around weeks 8 or 9 of pregnancy and subside after 12-14 weeks. However, in $10 \%$ of pregnancies symptoms may continue beyond 20 weeks and even until birth. In about 0.3 to $3 \%$ of pregnant women, severe form of nausea and vomiting can result in to $\mathrm{HG}^{4}{ }^{4}$ The incidence appears to vary with ethnicity and ranges between 3 and 20 per 1,000 pregnancies. ${ }^{5}$ It is more 
commonly diagnosed in women in India, Pakistan, Asian, New Zealanders compared to European, American Indian, and Eskimo populations. ${ }^{6}$ It can lead to dehydration, weight loss and electrolyte imbalance and often requires hospitalization. HG is associated with a higher incidence of low birth babies (LBW), small-for gestational age (SGA) and premature babies. ${ }^{7,8}$ Munch et al in year 2011 documented that only $56 \%$ of women with vomiting seek medical advice. Rest $34 \%$ if vomiting persists may land up into vitamin deficiency and hypoproteinaemia in early trimester itself. ${ }^{9}$ Health awareness, lifestyle changes and dietary modifications, if these things are added in the antenatal care services, then definitely, they will enjoy their pregnancy status with fruitful outcome. Detail history is important where minor ailments like faulty dietary habits, starvation for religious reason will exacerbate the vomiting in early pregnancy. ${ }^{10}$ It is very important to identify the duration of vomiting and impairment of maternal health as early as possible in early pregnancy. Thus, correction of megaloblastic anaemia, control of urinary tract infection done as routine for better pregnancy outcome. Clinically there is need to identify group of women with impairment of metabolic and electrolyte function along with nutritional deficiency. High risk patients for weight loss should be picked up as early as possible. ${ }^{11}$ With this aim the present study was conducted on 100 cases of women in tertiary care centre. With this background prospective observational study 100 cases were conducted at tertiary health care centre. PCMS, RC with aim to identify clinical and laboratory parameters in cases of excessive vomiting. Study may help in evaluating what is major clinical problem encountered during treatment and how many days of care is needed in such cases.

\section{METHODS}

This was a hospital based prospective observational study conducted from 1st November 2019 to 30th April 2021 at department of obstetrics and gynecology, People's college of medical sciences and research centre Bhopal. Patients attending the ANC clinic and emergency indoor cases were considered as study population. 100 patients who satisfied inclusion and exclusion criteria were included in the study. Sampling technique used was convenience sampling, a type of non-probability sampling. After obtaining ethical clearance from institute's ethical committee, all the females fulfilling inclusion criteria and giving consent for the study were enrolled.

\section{Inclusion criteria}

Patients with early pregnancy with excessive vomiting up to 13 weeks were included in the study.

\section{Exclusion criteria}

Patients with vomiting after 13 weeks and patients not willing to participate in study. were excluded from the study.
Written consent was obtained from all the study participants after explaining them nature and purpose of study. They were ensured that confidentiality will be maintained and option to withdraw from the study was always kept open. Data regarding sociodemographic variables was obtained from all the study participants and entered in questionnaire. All the females were enquired about obstetric variables in detail. Their exact period of Gestation on day of reporting was calculated. And full history regarding parity, abortions, singleton or multifetal pregnancy was obtained from all the female. History regarding presenting complaints such as nausea, vomiting etc. with their duration and characteristics was obtained. Detail examination of vitals, such as pulse, blood pressure, signs and symptoms of dehydration such as dryness of tongue, sunken eyes, skin turgosity, urine output etc. were assessed. Analysis of all women was scrutinized for other associated conditions like multiple pregnancy, hepatitis, hypertensive disorders and required investigations was performed as per, format and consent. Following treatment protocol was planned to judge their response for the therapy in hospitalized patient:

First drug of choice on day 1 of admission-Injection doxinate $10 \mathrm{mg}$ IM and injection pyridoxine $10 \mathrm{mg}$ IM and diphenyl hydramine.

Second line of drug was-Injection promethazine and prochlorpromazine.

Third line of drug-Injection metaclopromide $10 \mathrm{mg}$ IV QID and injection ondensetron 4 mg IV TDS. ${ }^{12}$

For intractable vomiting-enteral and parenteral nutrition needed. For refractory cases-oral methylprednisolone 20 mg BD was planned. ${ }^{13,14}$

Very rarely last choice of intractable vomiting with serious health impairment is medical termination of pregnancy. ${ }^{15}$

According to the planned protocol $100 \%$ cases were responded to doxinate $10 \mathrm{mg}$ and pyridoxine $10 \mathrm{mg}$, IV ondensetron 4 mg. ${ }^{16}$

Results obtained were tabulated and analysed statistically using SPSS software.

\section{RESULTS}

On statical analysis of 100 cases maximum $48 \%$ cases were in the age group 21-25 years. Next 32\% belonged to age group of 26-30 years. Eldest age group of 31-35 years constituted $13 \%$ of study group. Mean age of women having vomiting in pregnancy was 25.79 year. There was no patient with teenage pregnancy. Out of 100 cases, $51 \%$ were multigravida, and $49 \%$ were primigravida. Second third and fourth gravida were $30 \%, 15 \%$ and $2 \%$ respectively. The $19 \%$ had past history of abortions. Out of them $78 \%$ had one abortion in past. The $22 \%$ had more 
than two abortions. As regard to period of gestation, maximum $62 \%$ of patients were at $11-13$ weeks, $35 \%$ were of 7-10 weeks of gestation. In our study $66 \%$ (maximum) of cases had >five episodes of vomiting, while $11 \%$ had 4 episodes, $3 \%$ had 6 episodes, $8 \%$ had 7 episodes, $10 \%$ had 8 episodes as well as $2 \%$ had more than 10 episodes of vomits/ day. When frequency of vomiting was correlated with period of gestation. There was significant correlation between two chi square value $=23.149$ with $\mathrm{p}$ value of 0.046 .

Signs of dehydration like dryness of tongue, skin turgor and sunken eyes were observed and recorded. Dryness of tongue was found in $11 \%$ cases; skin turgor was poor in $19 \%$ cases while sunken eyes were observed in twenty-two percentage of cases. All three parameters showed positive association with severity of vomiting. Skin turgor was prominent feature in patients who had more than five episodes of vomits. Dryness of the eyes found typically in the patients who had more than seven episodes of the vomiting per day.
Laboratory parameters like ketone bodies, sugar, albumin and pus cells in urine and serum alkaline phosphatase levels were studied. It was observed that $24 \%$ cases developed ketone bodies. There was strong correlation (chi square value 40.050) between number of episodes of vomiting and presence of ketone bodies. Among 100 cases, urine microscopic examination was conducted. $38 \%$ were having pus cell $2-3 / \mathrm{HPF}$. However only $11 \%$ had more than $4-5$ pus cells, $8 \%$ were with more than 5 pus cells on microscopic examination of urine and rest $43 \%$ were having no pus cells in urine sample. On subsequent evaluation, urine culture report was positive only in $2 \%$. There was strong co-relation between number of episodes of vomiting and presence of pus cell in urine having chi square $=26.843, \mathrm{p}=0.0081$. Albuminuria was not observed in any case with vomiting. In our study 11 patients developed glycosuria with significant Chi square $=49.472$. It was observed that among 100 cases, $91 \%$ patients were having normal alkaline phosphatase level $(<115)$ and rest $9 \%$ had raise serum alkaline phosphatase levels $>115$, which is significant $\mathrm{p}=0.000 \mathrm{Chi}$ square $=49.472$.

Table 1: Distribution of participants according to age, parity and period of gestation.

\begin{tabular}{|lll|}
\hline Variables & No. of patients & Percentage $(\%)$ \\
\hline Age (years) & 7 & 7.0 \\
\hline$\leq 20$ & 48 & 48.0 \\
\hline $21-25$ & 32 & 32.0 \\
\hline $26-30$ & 13 & 13.0 \\
\hline$>30$ & & \\
\hline Parity & 51 & 51.0 \\
\hline Multi & 49 & 49.0 \\
\hline Primi & & \\
\hline Gestation age (weeks) & 3 & 3.0 \\
\hline$\leq 6$ & 35 & 35.0 \\
\hline $7-10$ & 62 & 62.0 \\
\hline $11-13$ & & \\
\hline
\end{tabular}

Mean age of participants was $25.79 .51 \%$ were multigravida. Mean gestational age was 10.71 weeks.

Table 2: Association of clinical parameters with episodes of vomiting per day.

\begin{tabular}{|c|c|c|c|c|c|c|c|c|c|c|}
\hline \multirow{2}{*}{ Variables } & \multicolumn{7}{|c|}{ Vomiting } & \multirow{2}{*}{$\begin{array}{l}\text { Chi square } \\
\text { value }\end{array}$} & \multirow{2}{*}{ Df } & \multirow{2}{*}{ P value } \\
\hline & 4.00 & 5.00 & 6.00 & 7.00 & 8.00 & 10.00 & Total & & & \\
\hline \multicolumn{11}{|l|}{ Age (year) } \\
\hline$\leq 20$ & 1 & 4 & 0 & 1 & 1 & 0 & 7 & \multirow{4}{*}{17.839} & \multirow{4}{*}{15} & \multirow{4}{*}{$\begin{array}{l}0.025 \\
\text { (Significant) }\end{array}$} \\
\hline $21-25$ & 8 & 32 & 1 & 3 & 4 & 0 & 48 & & & \\
\hline $26-30$ & 1 & 23 & 1 & 4 & 1 & 2 & 32 & & & \\
\hline$>30$ & 1 & 7 & 1 & 0 & 4 & 0 & 13 & & & \\
\hline \multicolumn{11}{|l|}{ Parity } \\
\hline Multi & 6 & 35 & 2 & 3 & 4 & 1 & 51 & \multirow{2}{*}{38.427} & \multirow{2}{*}{15} & \multirow{2}{*}{$\begin{array}{l}0.003 \\
\text { (Significant) }\end{array}$} \\
\hline Primi & 5 & 31 & 1 & 5 & 6 & 1 & 49 & & & \\
\hline \multicolumn{11}{|c|}{ Period of gestation (weeks) } \\
\hline$\leq 6$ & 0 & 3 & 0 & 0 & 0 & 0 & 3 & \multirow{3}{*}{23.249} & \multirow{3}{*}{15} & \multirow{3}{*}{$\begin{array}{l}0.046 \\
\text { (Significant) }\end{array}$} \\
\hline $7-10$ & 5 & 21 & 2 & 3 & 3 & 1 & 35 & & & \\
\hline $11-13$ & 6 & 42 & 1 & 5 & 7 & 1 & 62 & & & \\
\hline \multicolumn{11}{|l|}{ Tongue } \\
\hline Not dry & 10 & 62 & 3 & 7 & 7 & 0 & 89 & \multirow{2}{*}{34.722} & \multirow{2}{*}{5} & \multirow{2}{*}{$\begin{array}{l}0.000 * \\
\text { (Significant) }\end{array}$} \\
\hline Dry & 1 & 4 & 0 & 1 & 3 & 2 & 11 & & & \\
\hline
\end{tabular}




\begin{tabular}{|c|c|c|c|c|c|c|c|c|c|c|}
\hline \multirow{2}{*}{ Variables } & \multicolumn{7}{|c|}{ Vomiting } & \multirow{2}{*}{$\begin{array}{l}\text { Chi square } \\
\text { value }\end{array}$} & \multirow[b]{2}{*}{ Df } & \multirow{2}{*}{ P value } \\
\hline & 4.00 & 5.00 & 6.00 & 7.00 & 8.00 & 10.00 & Total & & & \\
\hline \multicolumn{11}{|l|}{ Turgor } \\
\hline Normal & 8 & 58 & 3 & 5 & 7 & 0 & 81 & \multirow{2}{*}{31.911} & \multirow{2}{*}{5} & $0.000 *$ \\
\hline Poor & 3 & 8 & 0 & 3 & 3 & 2 & 19 & & & (Significant) \\
\hline \multicolumn{11}{|l|}{ Eyes } \\
\hline Not Sunken & 7 & 57 & 3 & 5 & 6 & 0 & 78 & \multirow{2}{*}{58.332} & \multirow{2}{*}{5} & \multirow{2}{*}{$\begin{array}{l}0.000 * \\
\text { (Significant) }\end{array}$} \\
\hline Sunken & 4 & 9 & 0 & 3 & 4 & 2 & 22 & & & \\
\hline
\end{tabular}

Signs of dehydration like dryness of tongue was present in 11\%, poor skin turgor with $19 \%$ and Sunken eyes with $22 \%$ of cases. Dryness of tongue, skin turgor and sunken eyes showed significant association with episodes of vomiting.

Table 3: Association of laboratory parameters with episodes of vomiting per day.

\begin{tabular}{|c|c|c|c|c|c|c|c|c|c|c|}
\hline \multirow{2}{*}{ Variables } & \multicolumn{7}{|c|}{ Vomiting } & \multirow{2}{*}{$\begin{array}{l}\text { Chi square } \\
\text { value }\end{array}$} & \multirow{2}{*}{ Df } & \multirow{2}{*}{ P value } \\
\hline & 4.00 & 5.00 & 6.00 & 7.00 & 8.00 & 10.00 & Total & & & \\
\hline \multicolumn{11}{|l|}{ Ketones } \\
\hline Absent & 9 & 53 & 1 & 5 & 8 & 0 & 76 & \multirow{2}{*}{40.050} & \multirow{2}{*}{5} & \multirow{2}{*}{$\begin{array}{l}0.000 * \\
\text { (Significant) }\end{array}$} \\
\hline Present & 2 & 13 & 2 & 3 & 2 & 2 & 24 & & & \\
\hline \multicolumn{11}{|l|}{ Pus cells } \\
\hline Absent & 3 & 35 & 1 & 1 & 3 & 0 & 43 & \multirow{4}{*}{26.843} & \multirow{4}{*}{5} & \multirow{4}{*}{$\begin{array}{l}0.0081 \\
\text { (Significant) }\end{array}$} \\
\hline 2 cells (present) & 3 & 26 & 1 & 4 & 3 & 1 & 38 & & & \\
\hline 4 cells (present) & 4 & 4 & 0 & 2 & 1 & 0 & 11 & & & \\
\hline 5 cells (present) & 1 & 1 & 1 & 1 & 3 & 1 & 8 & & & \\
\hline \multicolumn{11}{|l|}{ Sugar (in urine) } \\
\hline Absent & 6 & 64 & 3 & 7 & 8 & 1 & 89 & \multirow{2}{*}{49.472} & \multirow{2}{*}{5} & \multirow{2}{*}{$\begin{array}{l}0.000 * \\
\text { (Significant) }\end{array}$} \\
\hline present & 5 & 2 & 0 & 1 & 2 & 1 & 11 & & & \\
\hline \multicolumn{11}{|c|}{ Alkaline phosphatase } \\
\hline Normal & 11 & 61 & 3 & 7 & 7 & 2 & 91 & \multirow{2}{*}{49.472} & \multirow{2}{*}{5} & \multirow{2}{*}{$\begin{array}{l}0.000^{*} \\
\text { (Significant) }\end{array}$} \\
\hline Raised & 0 & 5 & 0 & 1 & 3 & 0 & 9 & & & \\
\hline
\end{tabular}

There was strong correlation between number of episodes of vomiting and presence of ketone bodies. A strong relation between number of episodes of vomiting and presence of pus cell in urine microscopy was also found. $11 \%$ patients developed glycosuria, while $9 \%$ had raised serum alkaline phosphatase levels.

\section{DISCUSSION}

Chortatos et al in their study observed in a sample of total 17,070 cases, $33 \%$ reported with vomiting. It was prevalent in age group of 24-30 years. ${ }^{17}$ Mean age of cases in our study was 25.79 years.

With regards to parity, in our study $49 \%$ were primigravida and rest $51 \%$ were multigravida. While metanalysis of Einarson et al identified $67 \%$ primigravida and 33\% multigravida. ${ }^{18}$

Coronado et al conducted study on 263 pregnant women with gestational age $<12$ weeks with prevalence of vomiting as $29.3 \% .^{2}$ Harrell et al in his study on 100 cases, found $80 \%$ women had vomiting at 10-12 weeks and 20\% cases $<8$ weeks, indicating vomiting episodes increase with period of gestation till 12 weeks. ${ }^{19}$ Similarly in our study, peak occurrence of vomiting was seen at 11-13 weeks, in $62 \%$ cases. Only in 3\% cases vomiting was observed at 6 weeks of gestation.

Study conducted by Bai et al conducted study on 5,079 women with vomiting and found that $44.4 \%$ were symptomatic with dehydration and fatigue. ${ }^{20}$ In our study, signs of dehydration were found in $22 \%$ cases, which is lower than previous study.

On planned investigations of urine sample of all 100 women was analysed for presence of ketone bodies it was observed that $50 \%$ of patients with excess of vomiting $(n=8)$ had ketone bodies in the urine. Simultaneously hypoglycaemia was also detected in these women. Koot et al conducted a study on 215 women, observed that nausea and vomiting was not significantly associated with ketonuria. However, duration of hospital stay had significant correlation with ketoneurea. ${ }^{21}$ In study conducted by Morali et al ketonuria was significantly more severe $(p<0.01)$ in the abnormal enzyme group, implying a more severe state of starvation and dehydration. The correlation coefficient between the degree of ketonuria and level of liver enzymes was low for alkaline phosphatase in his study ( $\mathrm{r}=0.18)$, GPT $(\mathrm{r}=0.15)$, and GOT $(\mathrm{r}=0.28) .{ }^{22} \mathrm{On}$ analysis of liver function test deranged liver enzymes were observed in $9 \%$ of cases. Similar observation was made by Morali et al in year 2012 where 14\% patients had raised serum alkaline phosphatase in their sample of 80 cases. $^{23}$

With regard to association of urinary tract infection with vomiting in pregnancy only $2 \%$ had urinary tract infection with positive urine culture sample. The $57 \%$ had pus cells 
on microscopic examination and they had asymptomatic bacteriuria. The $43 \%$ women urine sample was normal on microscopic examination. Chiong et al demonstrated UTI was diagnosed in $15 / 292$ subjects $(5.1 \%){ }^{24}$

In our study, there was no case identified with hypovitaminosis and hypoproteinaemia. Serum electrolytes were estimated in all patients and alkalosis was not detected, neither hypervitaminosis nor hypoproteinaemia was identified. Clinically none of the patient had other reasons for vomiting like cholecystitis, appendicitis, pancreatitis, peptic ulcer, renal calculus, red degeneration of fibroid and twisted ovarian tumours. None of the patients needed correction for alkalosis.

\section{CONCLUSION}

All cases with vomiting in early pregnancy should receive adequate clinical attention. Exclusion of all emergency clinical conditions should be done on routine basis. Patient should be screened for urine tract infection and diabetes in all cases.

\section{Funding: No funding sources}

Conflict of interest: None declared

Ethical approval: The study was approved by the Institutional Ethics Committee

\section{REFERENCES}

1. Fell DB, Joseph KS. Outcome of pregnancies complicated by hyperemesis gravidarum. Obstet Gynecol. 2006;107:285-92.

2. Fell DB, Dodds L, Joseph KS. Risk factors for hyperemesis gravidarum requiring hospital admission during pregnancy. Obstet Gynecol. 2006;107:277-84.

3. Soules Conchillo JM, Koek GH. Hyperemesis gravidarum and severe liver enzyme elevation. J Hepatol. 2002;37:162-6.

4. Coronado PJ, Fasero M, Álvarez-Sánchez A, Rey E. Prevalence and persistence of nausea and vomiting in pregnancy. Rev Esp Enterm Drg. 2014;106,5:318-24.

5. Lee N, Saha S. Nausea and vomiting of pregnancy. Gastroentrol North Am. 2011;40(2):309:74.

6. Dodds MR, Hughs CL, Garcia JA. Nausea and vomiting of pregnancy: role of human chorionic gonadotropin and 17-hydroxyprogesterone. Obstet Gynecol. 1980;55:696.

7. Russo-Stieglitz KE, Levine AB, Wagner BA. Pregnancy outcome in patients requiring parenteral nutrition. J Matern Fetal Med. 1999;8:164-7.

8. Holmgren C, Aagaard-Tillery KM, Silver RM. Hyperemesis in pregnancy: an evaluation of treatment strategies with maternal and neonatal outcomes. Am J Obstet Gynecol. 2008;198:56.e1-56.e4.
9. Munch S. Women's experiences with a pregnancy complication: causal explanations of hyperemesis gravidarum. Soc Work Health Care. 2002;36:519-24.

10. Jueckstock JK, Kaestner R, Mylonas I. Managing hyperemesis gravidarum: a multimodal challenge. BMC Medicine. 2010;8:46.

11. Gross S, Librach C, Cecutti A. Maternal weight loss associate with hyperemesis gravidarum: a predictor of fetal outcome. Am J Obstet Gynecol. 1989;160:906.

12. McParlin C, O'Donnell A, Robson SC, Beyer F, Moloney E, Bryant A et al. Treatments for Hyperemesis Gravidarum and Nausea and Vomiting in Pregnancy: A Systematic Review. JAMA. 2016;316(13):1392-1401.

13. Safari HR, Alsulyman OM, Gherman RB. Experience with oral methylprednisolone in the treatment of refractory hyperemesis gravidarum. Am J Obstet Gynecol. 1998;178:1054-8.

14. Yost NP, McIntire DD, Wians FH. A randomized, placebo-controlled trial of corticosteroids for hyperemesis due to pregnancy. Obstet Gynecol. 2003;102:1250-4.

15. Poursharif B, Korst LM, Macgibbon KW, Fejzo MS, Romero R, Goodwin TM. Elective pregnancy termination in a large cohort of women with hyperemesis gravidarum. Contraception. 2007;76:451-5.

16. Sullivan CA, Johnson CA, Roach $\mathrm{H}$, et al. A pilot study of intravenous ondansteron for hyperemesis gravidarum. Am J Obstet Gynecol. 1996;174:1565-8.

17. Chortatos A, Haugen M, Iversen PO, Vikanes A, Magnus $\mathrm{P}$, Veierod MB. Nausea and vomiting in pregnancy: associations with maternal gestational diet and lifestyle factors in the Norwegian mother and child cohort study. BJOG. 2013;120(13):1642-53.

18. Einarson TR, Piwko C, Koren G. Quantifying the global rates of nausea and vomiting of pregnancy: a metaanalysis. J Population Therapeutics Clin Pharmacol. 2013;20(2):e171-83.

19. Harrell HE. High prevalence of severe nausea and vomiting of pregnancy and hyperemesis gravidarum among relatives of affected individuals. Eur J Obstet Gynecol Reprod Biol. 2008;141(1):13-7.

20. Bai G, Korfage IJ, Groen EH, Jaddoe VWV, Mautne E. Associations between Nausea, Vomiting, Fatigue and Health-Related Quality of Life of Women in Early Pregnancy. PloS one. 2016.

21. Grooten IJ, Koot MH, Van Der Post JAM. Early enteral tube feeding in optimizing treatment of hyperemesis gravidarum. Am J Clin Nutr. 2017;106(3):812-20.

22. Morali GA, Braverman DZ. Abnormal liver enzymes and ketonuria in hyperemesis gravidarum. J Clin Gastroenterol. 1990;12:303-5.

23. Conchillo JM, Koek GH. Hyperemesis gravidarum and severe liver enzyme elevation. J Hepatol. 2002;37:1626.

24. Chiong P. Screening for urinary tract infection in women with hyperemesis gravidarum. J Obstet Gynaecol Res. 2012;38(1):145-53

Cite this article as: Dubey D, Agrawal U, Sapkal R. A study to identify clinical and laboratory parameters in cases of excessive vomiting in early pregnancy. Int J Reprod Contracept Obstet Gynecol 2021;10:4424-8. 